\title{
NEUMANNIAN ECONOMY IN MULTI-AGENT APPROACH. INVESTIGATION OF STABILITY AND INSTABILITY IN ECONOMIC GROWTH
}

\begin{abstract}
Katalin Martinás*
Department of Atomic Physics, Eötvös Loránd Technical University

Budapest, Hungary

\section{SUMMARY}

Axiomatic foundation of non-equilibrium microeconomics is outlined. The economic activity is modelled as transformation and transport of commodities (materials) owned by the agents. Rate of transformations (production intensity), and the rate of transport (trade) are defined by the agents. Economic decision rules are derived from the observed economic behaviour. The non-linear equations are solved numerically for the Neumannian economy. The emergence of the equilibrium market structure appears as an order out of chaos process.
\end{abstract}

\section{KEY WORDS}

economics, irreversibility, growth, chaos

\section{CLASSIFICATION}

JEL: C62, O12 


\section{INTRODUCTION}

Neumann, in his 1937 paper introduced a model economy to study the conditions for equilibrium growth [1]. In the present paper the Neumannian economy will be investigated in an irreversible (thermodynamic like) multi-agent approach.

There is a basic similarity between chemistry and economics, namely that they are concerned with transformation and transport of material. Formal description of the material flows in economics and in chemistry lead to equations of the same structures, with some important differences. In thermodynamics the laws of transport and transformations are formulated as the First and Second Law of Thermodynamics. The analogous formulation in economics for the First Law is trivial [2]. Economic activity can be described via the changes of the quantities of goods. Second Law states that the purpose of economic activity to be better off (later we give a more precise definition). The First Law, in its direct or indirect form, was already articulated by economists. The classical economists accepted it. Neoclassical approach considers it trivial and non-important. Second Law is applied in a stronger form. We always choose the best possibility.

Organization of the paper is as follows. In Section 2 the thermodynamic description of chemical systems will be outlined. First and Second Law will be given in such form, which can be applied also in economics. In Section 3 a thermodynamic (or irreversible) microeconomics is outlined. In Section 4 we give numerical solutions for the Neumannian economy [1]. The results show a chaos-order-chaos behaviour.

\section{THERMODYNAMICS}

\section{A BRIEF SUMMARY OF THE HISTORY OF ECONOMICS AND THERMODYNAMICS}

Analogous properties of chemical and economic processes are well known for a long time. Kalman Szily, a physicist, gave a lecture in 1871 with the title Communistic state of the physical world, where he used some economic examples to explain the First and Second Law of Thermodynamics. In 1903, Jankovich [3] published a paper on the mechanical foundation of value. Imre Fenyes, professor of thermodynamics, emphasized the similarity between the economic goods and the thermodynamic quantities. Here we can cite hints by von Neumann [4], Samuelson [5], Moffat [6] and Berry and Andresen [7], among others. In an excellent summary on the use of physical analogies by an early neoclassic [8], Mirowski writes: "The metaphor of energy/utility which neoclassical economics appropriated was derived from the physics of a specific historical period: the years of the mid nineteenth century just prior to the elaboration of the second law of thermodynamics." [9]. Yet, pre-entropic physics has been basically a theory based on mechanical considerations, without a "time-arrow", without irreversibility.

There were several attempts to exploit the analogous properties of the thermodynamic entropy and the utility concept of neoclassical economics [10]: Rozonoer [11, 12], Bródy et al. [13], or utility and internal energy [14], Stepanic et al [15], Mironova, Amelkin and Tsirlin [16]. These analogies are useful but different from the irreversible approach. 


\section{LAWS OF THERMODYNAMICS}

There are two basic approaches to understand the equilibration process: a macro (thermodynamics) and a micro (statistical mechanics) approach. Nowadays the statistical approach is more popular. Statistical mechanics, developed initially by Ludwig Boltzmann, defines entropy as the logarithm of the number of "microstates". Boltzmann's definition of entropy rather suggests the order/disorder metaphor. Boltzmann's statistical approach is a useful tool in a wide range of applications.

Classical (or phenomenological) thermodynamics starts from the observed properties of our material world.

\section{First Law}

In thermodynamic investigations it is worthwhile to distinguish between the extensive variables (volume, energy) and intensive variables (e.g. temperature, pressure). An extensive variable must satisfy two conditions. First, its time dependence is described by the generic balance equation:

$$
\mathrm{d} X / \mathrm{d} t=J+G,
$$

where $J$ is the flux, and $G$ is a generalized source term. Second, it must be additive, in the sense that if $X^{\mathrm{a}}$ and $X^{\mathrm{b}}$ are values of the variables for two systems $a$ and $b$, the variable has the value $X^{\mathrm{a}}+X^{\mathrm{b}}$ for the combined system, consisting of the union of the two. A general rule of thermodynamics states that all the interactions of the thermodynamic system with its environment take place through the flows of extensive variables. Mass, energy, the number of molecules and total volume are examples of extensive properties. That property is summarized in the First Law.

First Law: Any simple system has particular states that are characterized completely by extensive quantities.

The postulate reflects an important feature of thermodynamic systems. The evolution of the system is governed by the balance equations of extensive quantities, in the form:

$$
\mathrm{d} X_{\mathrm{ki}} / \mathrm{d} t=\sum_{\mathrm{kl}, \mathrm{i}} J_{\mathrm{kl}, \mathrm{i}}+G_{\mathrm{ki}},
$$

where index $i$ and $l$ identify the subsystem, $X_{i k}$ is the quantity of the extensive parameter $k, J_{\mathrm{ill, \textrm {k }}}$ denotes the flow from the system 1 to the system $\mathrm{i}$.

The independent set of extensive variables necessary to describe a given system is determined essentially by trial and error. The choice is not unique. It depends on one's purpose or (from another perspective) on the accuracy of one's measurements. For example, consider the air in a room. For certain purposes it is sufficient to treat it as an equilibrium gas. But for a more precise measurement one has to take all the different types of molecules present in the air into account. In still more precise calculations one might also consider the different isotopes. Going to extremely fine details it might be necessary to consider the internal structures of the atoms. In real calculations it is necessary that we take into account only those details what are important for the problem in question.

\section{Second Law}

The Second Law of thermodynamics is essentially different from the First Law, since it deals with the direction in which a process takes place in nature. It expresses the preferences of Nature. Not every change which is consistent with the balance equations is a possible change. The conservation laws do not suffice for a unique 
determination of natural processes. As for instance, in the previous example, the water equation offers no information, whether hydrogen and oxygen actually combine to form water, or water decomposes into hydrogen and oxygen or whether such a process can go into both directions.

The essence of the Second law is that all the independent elementary (infinitesimal) processes that might take place may be divided into three types: natural processes, unnatural (forbidden) processes, and reversible processes:

- natural processes are all such that actually do occur (e.g., heavy body falls down),

- unnatural processes (the reverse of natural processes); such processes never occur spontaneously, only as the forced processes,

- as a limiting case between natural and unnatural processes are the reversible processes. They do not actually occur, but they are important for mathematical causes.

The Second Law implies a relation between the quantities connected with the initial and final states of any natural process. The final state of a natural process has to be discriminated from the initial state, while in a reversible process they have to be in some sense equivalent.

\section{Non-equilibrium thermodynamics - Dynamics}

The balance equations describe the time evolution of the systems, the relation of flows and the distribution of stocks has to be defined empirically. These relations are empirical, material dependent, but not arbitrary. The flows must obey the Second Law. That condition has a great power. It allows us to introduce the concept of thermodynamic forces, and the force law which connects the flows with the state variables.

The uni-directionality of natural processes is formulated in the form of a dynamic law in non-equilibrium thermodynamics. The change (flow) is proportional to the force (difference in intensive parameters, $\delta Y_{k}$ )

$$
J_{\mathrm{i}}=\sum_{\mathrm{k}} L_{\mathrm{ik}} \delta Y_{\mathrm{k}}
$$

where $L$ is the so called conductivity matrix. It is positive definite. That property of matrix $L$ follows from the Second Law. That is the "time's arrow". Thermodynamic based microeconomics.

\section{IRREVERSIBLE ECONOMICS}

For the mathematical structure of irreversible microeconomics see [17]. Here we summarize the most important definitions and concepts [18].

An economic agent (EA) is defined for our purposes as the smallest entity with an implicit or explicit decision-making rule. An EA would normally be either a firm or an individual. EA are characterized by their scope of activities, by their knowledge, experiences and by their stocks of goods and money. Our primary interest is the change of stocks and its economic effect. Every stock which can be affected by the economic activity of an agent can be listed, and those also, which affect the economic activity of the agent. The list of goods may contain the money, but it is not necessary.

An agent consumes, produces or exchanges the goods. In consumption the quantity change is always negative. Production is a transformation of stocks from the initial form to a final form. Here the change is positive for the products and byproducts, and negative for the input materials. Total quantity increases only when there is an input 
from the nature. Otherwise the obligatory losses decrease the total quantity of goods. Trade modifies only the owner of stocks. Economic actions are trade and production.

Trade and production are described as decisions. EA selects or rejects the offers provided by other EAs or (in case of production) by his/her internal state.

Decisions are tantamount to selections from a limited set of possibilities for immediate action. The set of possibilities is constrained by the external environment (for example, the legal framework) and by the assets of the agent, including financial assets, physical assets and intangibles such as knowledge, know-how, reputation, and so on.

Proposition 1 (First Law): Evolution of an economic system is described by the balance equation for stocks of goods and money.

Proposition 2 (Second Law of Economics): The purpose of economic action is to increase the expected economic welfare.

There is no economic action decreasing the expected economic welfare. It is the no loss rule. That rule implies that every agent has a measure to rank her/his belongings as a measure of economic welfare. The economic welfare of an economic agent is a function of the stocks of goods and money belonging to the economic agent: $Z=Z(X)$ The proof is given in [17]. Sign convention is selected so that $\mathrm{d} Z>0$ for allowed (no-loss) processes, and $\mathrm{d} Z<0$ for forbidden (loss-making) transactions.

Assuming the function $Z$ is continuous and differentiable, the partial derivatives in respect of the stocks can be interpreted as the marginal $Z$-value of the good $i$. It is measured in welfare/quantity units. Let $M$ is for the quantity of the money owned by the agent. The marginal $Z$-value of money is the marginal change of the welfare, that is: $w_{M}=\partial Z / \partial M$. The marginal value of the good $\mathrm{i}$ is:

$$
v_{i}=\frac{\partial Z / \partial X_{i}}{\partial Z / \partial M}
$$

The expected change of economic welfare is:

$$
\mathrm{d} Z=w_{\mathrm{M}}\left(\sum_{\mathrm{i}} v_{\mathrm{i}} \mathrm{d} X_{\mathrm{i}}+\mathrm{d} M\right)
$$

The expected gain (profit) in trade of a unit of good i for price $p_{\mathrm{i}}$ is $F=\left(v_{\mathrm{i}}-p_{\mathrm{i}}\right)$, the expected gain for production $F=v C . C_{\mathrm{i}}$ is the change of the $\mathrm{i}^{\text {th }}$ good in a unit production. It is positive for the products and by-products, and negative for the input materials.

The technology defines the production vector. The agent defines the production level. Technology (capital) gives an upper limit $\left(y_{\max }\right)$, but real systems work with less efficiency.

Assumption: Production level is proportional to expected profit, that is

$$
y_{\mathrm{n}}=L_{\mathrm{n}} v C \text {. }
$$

In trade the unit processes are given by the market institutions. Traded quantity when agent $k$ trades with the agent $m$ at price pi will be proportional to the expected gain, that is

$$
y_{\mathrm{km}, \mathrm{i}}=L_{\mathrm{km}, \mathrm{i}}\left(v_{\mathrm{i}}-p_{\mathrm{i}}\right) \text {. }
$$

Trade is viable only if the agent $m$ agrees the same quantity with opposite sign. Price, $p_{\mathrm{i}}$ comes form the solution of equation

$$
\sum_{\mathrm{nm}} y_{\mathrm{nm}, \mathrm{i}}=\sum_{\mathrm{nm}} L_{\mathrm{nm}, \mathrm{i}}\left(v_{\mathrm{i}}^{\mathrm{n}}-p_{\mathrm{i}}\right)=0,
$$

where the summation is for the agents participating in the bargaining process. 
The equation system is closed. (We omit the indices for the sake of clarity and brevity.)

Balance equations:

$$
\begin{gathered}
X(t+1)=X(t)+L(v-p)+L_{\mathrm{n}} v C C, \\
M(t+1)=M(t)-p L(v-p), \\
L(v-p)=0 .
\end{gathered}
$$

It is a non-linear coupled mapping. The properties can be investigated with numerical solutions. A numerical solution needs the following data:

- identification of the agents,

- the production vectors

- initial stocks,

- welfare function and the coupling parameters $(L)$.

Technological innovations and monetary policy of the economic system may also have to be specified. Further, exogenous effects such as consumption not connected with production, taxation, depreciation, and natural constraints, if any, must be specified.

\section{NEUMANN ECONOMY}

Our minimum model of an economy has 3 economic agents, corresponding to three sectors, namely: agriculture, industry, and households and we apply the simplifying assumptions of Neumann, namely:

- vector $C$ is constant,

- nature is infinite (there are free goods of nature in quantities without limit),

- consumption consists of two parts, a fixed part and a part which is proportional to the production,

- labour is considered as a normal stock (the households produce it),

- agents get interest payment for their money stock.

\section{SELECTION OF THE WELFARE FUNCTION}

For the present investigations a logarithmic welfare function was selected:

$$
Z_{\mathrm{n}}=\sum_{\mathrm{i}} X_{\mathrm{in}} \cdot \log \left(C_{\mathrm{n}} M_{\mathrm{n}} / X_{\mathrm{in}}\right),
$$

where $X_{\mathrm{in}}$ is the stock $\mathrm{i}$ of the agent $\mathrm{n}, M_{\mathrm{n}}$ is the money stock of the agent $n, C_{\mathrm{n}}$ is constant.

Production vectors: Agriculture $(2|-0,13|-0,08)$, Industry $(-4|2|-0,36)$ and Households $(-1,83|-1| 2)$.

The coupling parameter $L$ for all trades is assumed to be unity, viz. $L=1$. The production coupling parameters are: $L_{1}=0,352, L_{2}=0,288$ and $L_{3}=0,352$.

The interest rate is given for the money. After each cycle the money of the agents is multiplied with $\alpha$.

Initial stocks were selected as:

$\begin{array}{lllll} & \text { Money } & \text { Food } & \text { Tools } & \text { Labour } \\ \text { Agriculture } & 1000 & 22,98 & 18,51 & 14,07 \\ \text { Industry } & 1000 & 22,05 & 19,34 & 14,16 \\ \text { Households } & 1000 & 21,97 & 18,86 & 14,73\end{array}$




\section{NUMERICAL SOLUTIONS}

Figure 1 shows the intensity of production as a function of time. Time means here the number of completed cycles. The interest rate is $\alpha=1,0005$.

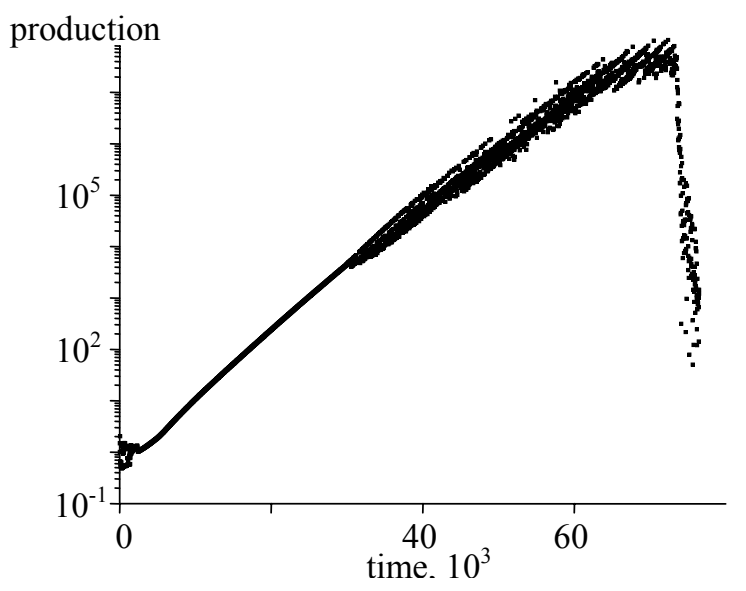

Fig. 1. Production as a function of time.

The system starts from chaos. The initial period (in a magnified form it is in Figure 2) is the non-equilibrium part. The initial stock distribution did not correspond to the equilibrium. Fig. 2 demonstrates the working of the invisible hand. Order develops from chaos. Fluctuations decrease, quasi-periodic oscillations emerge with decreasing amplitudes. The system finds the equilibrium path. There is a near-exponential growth of the production intensity. The equilibrium growth is stable only for $\alpha=1,0000$. Nevertheless the agents' welfare increases unequally. This inequality leads to the loss of stability, a new chaos appears.

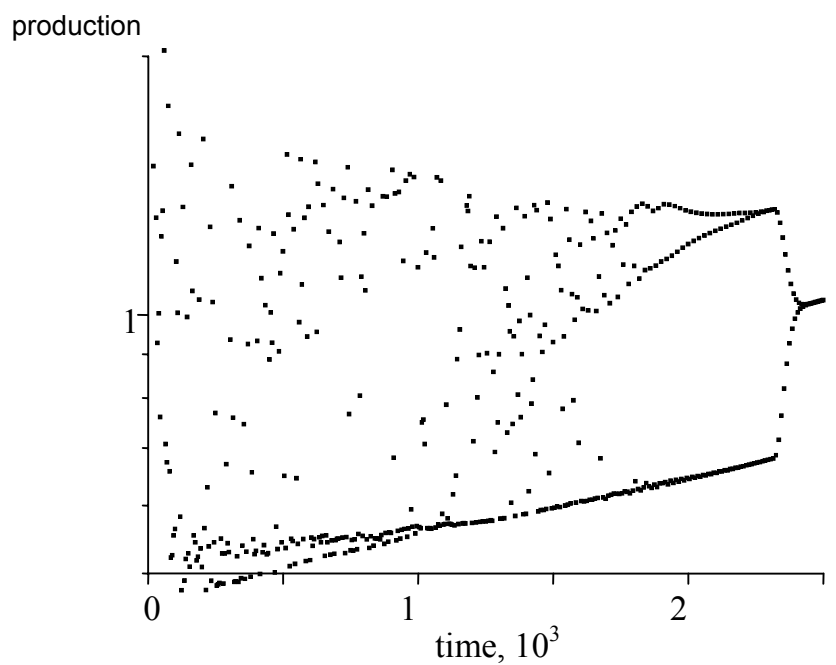

Fig. 2. Working of the invisible hand.

The time needed to reach the instability (or the collapse of economy) is called as the lifetime of the economy. Life time is defined by the technology (production vectors) and the interest rate. In Figure 3 the lifetime is plotted as a function of interest rate. The figures confirm Neumann's result, the golden result, for a given technology there is only one interest rate, which gives a stable growth. All the other interest rates give growth with limited stability, but in the nearly stable growth regimes the price ratio is nearly constant. 


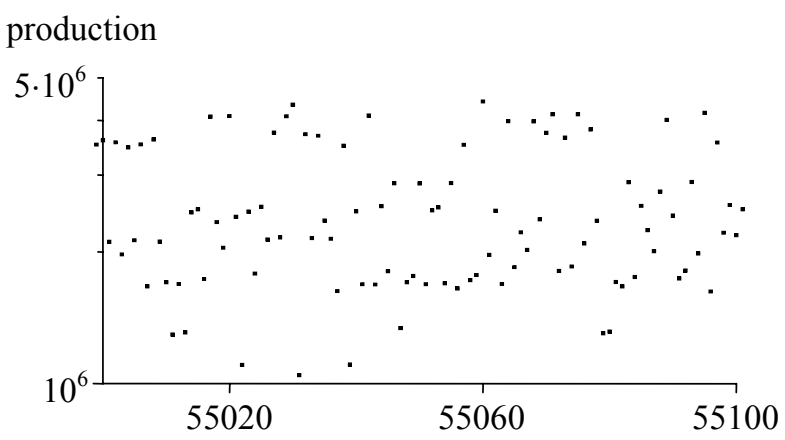

Fig. 3. Emergence of chaotic behaviour.

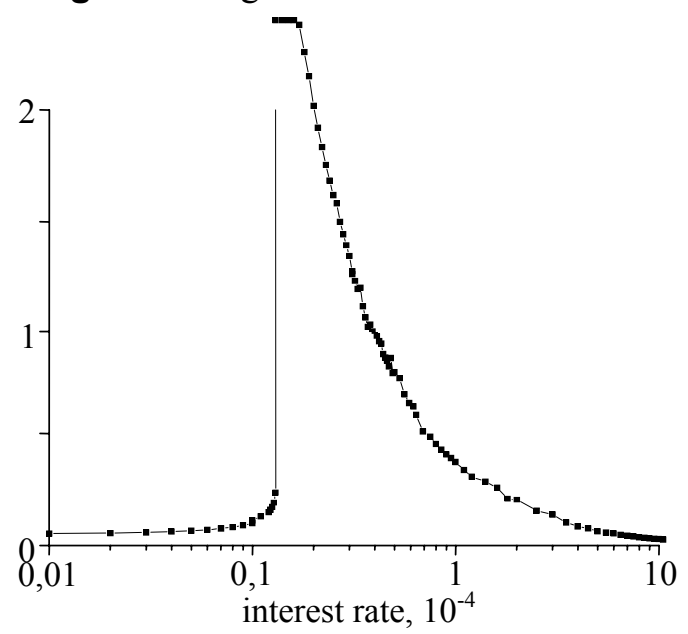

Fig. 4. Life time versus interest rate.

\section{ACKNOWLEDGMENT}

This paper is based on the results of a research program T: 043522, supported by the Hungarian Scientific Research Fund.

\section{REFERENCES}

[1] Zalai, E.: Matematikai közgazdaságtan.

KJK-Kerszöv Jogi és Üzleti Kiadó Kft., Budapest, 2000,

[2] Martinás, K.: Is the utility maximum principle necessary?

Fulbrook, E., ed.: Crisis in Economics. Routledge, London, 2003,

[3] Jankovich, B.: Mechanical foundation of value theory. In Hungarian.

Közg. Szemle 35, 10-23, 1903,

[4] von Neumann, J.: Über ein ökonomisches Gleichungssystem und eine Verallgemeinerung des Brouwerschen Fixpunktsatzes.

Ergebnisse eines mathematischen Kolloquiums 8, 73-83, 1937,

[5] Samuelson, P.A.: Thermodynamics and Economic Isomorphisms.

Adams-Hickman, F.G. and Hickman B.G., eds.: Global Econometrics. MIT Press, Cambridge, 1983,

[6] Moffat, M.J.: A Dynamic Model of Adaptive Economic Behaviour.

Taton, A., ed.: Sadi Carnot et l'essor de la thermodynamique. CNRS, Paris, 1976,

[7] Berry, R.S. and Andresen, B.: Thermodynamic constraints in economic analysis.

Schieve, W.C. and Allen, P.M., eds.: Self-organization and dissipative structures: Applications in the physical and social sciences. University of Texas Press, Austin, 1982, 
[8] Mirowski, P.: Physics and Marginalist Revolution. Journal of Economic History 44, 345-354, 1984,

[9] Mirowski, P., ed.: The reconstruction of economic theory. Kluwer-Nijhoff, Boston, 1986,

[10] Lihnierowicz, M.: Un modele d'echange economique (Economie et thermodinamique). Annales de l'Institut Henry Poincare, nouvelle serie. Section B 4(2), 159-200, 1970,

[11] Rozonoer, L.I.: Exchange and resource distribution (A generalized thermodynamic approach). I., II. and III.

Avtomatika i telemekhanika 5, 115-133, 6, 65-80, 8, 82-104, 1973,

[12] Rozonoer, L.I. and Tsirlin, A.M.: Optimal control of thermodynamic processes. I.-III. Automation and Remote Control 1983, Nos. 1, 2, 3,

[13] Bródy, A.; Martinás, K. and Sajó, K.: Essay on Macroeconomics. Acta Oeconomica 36, 305, 1985,

[14] Saslow, W.M.: Economic analogy to thermodynamics. American Journal of Physics 67, 1239, 1999,

[15] Stepanic, J.; Stefancic, H.; Zebec, M.S. and Perackovic, K.: Approach to a Quantitative Description of Social Systems Based on Thermodynamic Formalism. Entropy 2, 98-105, 2000,

[16] Mironova, V.A.; Amelkin, S.A. and Tsirlin, A.M.: Mathematical methods of finite-time thermodynamics. In Russian.

Khimia, Moscow, 2000,

[17] Martinás, K.: Irreversible Microeconomics.

Martinás, K. and Moreau, M., eds.: Complex Systems in Natural and Economic Sciences. Matrafüured, Budapest, 114-123, 1996,

[18] Ayres, R.U. and Martinás, K.: Wealth Accumulation and Economic Progress. Journal of Evolutionary Economics 6, 347-360, 1996.

\section{von Neumannova ekonomija u pristupu modeliranja pomoću agenata. Istraživanje stabilnosti i nestabilnosti u ekonomskom rastu}

K. Martinás

Odsjek za atomsku fiziku, Tehničko sveučilište Eötvös Loránd Budimpešta, Madžarska

\section{SAŽETAK}

Aksiomatski temelji neravnotežne mikroekonomije su skicirani. Ekonomska aktivnost modelirana je u obliku transformacije i transporta sredstava (materije) koje posjeduju agenti. Stopa transformacije (intenzitet proizvodnje) i stopa transporta (trgovina) definirani su agentima. Pravila ekonomskog odlučivanja izvedena su iz opaženog ekonomskog ponašanja. Nelinearne jednadžbe rješavane su numerički za von Neumannovu ekonomiju. Struktura ravnotežnog tržišta javlja se kao proces stvaranja reda unutar kaosa.

\section{KLJUČNE RIJEČI}

ekonomija, ireverzibilnost, rast, kaos 